\title{
Volunteering as a Tool of Formation of Social and Cultural Space of the University
}

\author{
Yulia S. Obidina \\ Tatyana V. Smyshlyaeva \\ Pavel S. Kozlov \\ Mari State University, Yoshkar-Ola, Russia \\ Email: basiley@mail.ru
}

Doi:10.5901/mjss.2015.v6n3s7p237

\begin{abstract}
This article deals with volunteering as one of the tools of formation of social and cultural space of the university. Volunteering is regarded as volunteerism based on the ideas of selfless service of people. The reasons for creation of volunteering, the main sphere of the volunteerism, the terms of the development of volunteering in the university and in the region are analyzed. The importance of the formation of the legal consciousness within volunteerism is noted. The authors of the article view the opportunity to apply the volunteering in different ways - on the basis of both historical situation existing in the society, the influence of the volunteering on the personality of the youth, and the essential tool for formation of social and cultural space of the region as a whole. The conclusion of the serious influence of the volunteering on the formation of civic position, legal consciousness, patriotism, tolerance of the youth is made on the basis of the extensive social and cultural and cross-cultural studies.
\end{abstract}

Keywords: volunteering, legal consciousness, social partnership, components of professional competency, social and cultural space, education of the youth

\section{Introduction}

Volunteering is a vital element of any modern society. Volunteering is determined as volunteerism based on the ideas of selfless service of humane ideals of mankind and not intended for profit making, getting experience or advancement (Pushkareva, 2013). The main purpose of volunteering is to get all-round satisfaction of private and social needs of the volunteers by the help other people. Working voluntarily for the good of other people citizens contribute significantly to social and economic development of their societies (Loginova, 2012, Sikorskaya, 2009). The good done by volunteers is permanent recognized in different programs oriented to distribution of volunteering world-wide and in Europe (Sherraden, 2008).

International organizations appeal the countries to regulate and encourage volunteering at the legislative level. The United Nations General Assembly adopted resolution 56/38 on 5 December 2001is recommended to create prosperous budget, legislative and other constrains including for community-based organizations and nonprofit of organizations participating in volunteering (Resolution A/RES/56/38 General Assembly of the United Nations).

The purpose of such policy is to encourage or inspire citizens to volunteering leaving the option open for person or the given organization (Bortnikova, 2012).

The Council of Europe also recommends the countries to determine the status of voluntary service at the national level focusing on its educational aspects and importance to the society. In some European countries special statutory legal acts operate which regulate volunteering (Italy, Spain, Portugal, Luxemburg, Rumania, the Czech Republic, Hungary, Poland, Lithuania, Macedonia, Moldova, Slovakia, Serbia, Ukraine) (Report of European Center of Not-for-Profit Law).

In the Universal Declaration on Volunteering accepted on January 2001 (which was announced as the Year of Volunteers) it is noticed that volunteering is a basis of the civil society because it gives the need in peace, freedom, safety, justice. In the Declaration it is underlined that volunteering is the way to save and strengthen human values, realize the rights and duties of the citizens, personal development through the perception of the human potential (Universal Declaration on Volunteering).

The functions of volunteering appear in voluntarism at the general and personal levels. Integrative, stabilization- 
related, motivation, law-creating (as a mean to create new ways of communication) functions belong to the general functions (Zhelezovskaya, 2011). Cognitive function, functions of self-cognition, socialization, self-affirmation are the personal functions. In our opinion, in spite of the mentioned functions of volunteering it is necessary to emphasize the social and pedagogical function focused on the pedagogical support and social adoption of the younger generation and also the social and cultural function (Chibisova, 2010) which allows to create an enabling environment of the region as a whole (Lough, 2011).

Today the youth of Russia is more than a quarter of the population. It is no coincidence that in the State of the Nation for the last five years the strong focus is placed on the problem solution among the youth which is determined by the challenges of the modern world and the demographic situation. The hearings to the state youth policy and the prospects of its development made by the Federation Council and also "The Strategy and the main aspects of the state youth policy in the Russian Federation till 2016" confirmed by the order of the Government of the Russian Federation as of December 18, 2006 represent the state significance of the youth problems and the formation of its legal consciousness (Strategy of state youth policy in the Russian Federation).

The question about the potential of the use of youth volunteering can be considered at least in to aspects: the influence of the youth volunteering on the specific historical situation existing in the society; the influence of volunteering on the personality of the youth involving in this situation (Ying, 2015, Nezhina, 2014, Sikorskaya, 2006). But there is a third aspect - volunteering is the essential tool to create the social and cultural space necessary for enabling functioning of the whole region (Huang, 2014).

In this case the model of the participation of students in creation of such space realized on the basis of volunteering was developed in the Mari State University.

The analysis of social and cultural problems of the development of the Republic Mari El allowed to distinguish as priority the following directions of volunteering which were realized within this model:

- legal education of children and youth;

- social and pedagogical support of children in the difficult life situation;

- social foster care of seniors;

- involving the foreign students to the process of socialization and formation of harmonic polycultural space.

In this way, the purpose of this article is to consider volunteering as one of the tool of creation of social and cultural space of the university on the example of the voluntarism in the Mari State University.

\section{Methods and Materials}

Volunteering has been working from 2001 in the Mari State University (Yoshkar-Ola).

According to this purpose within volunteering the following socially important issues are solved: preparation and realization of the legal education of students in different forms; creation of the system of social partnership with the government authorities, public and education organizations; supply of the interaction with other voluntary organization including interregional and international; carrying out special training of the participants of volunteering dealing with teaching; formation of tolerance in polycultural and multiconfessional region (Menscchikova, 2008).

Volunteers give lectures, legal discussions, round-tables, business games, which aim is to form legal consciousness, patriotism, and tolerance with the students of educational institutions of Yoshkar-Ola and the Republic Mari El. Only in 20148000 students of the educational institutions served as recipients. The theme of meetings and actions is diverse and actual: juvenile justice; realization of legal status of children and youth in the Russian Federation; electoral law and legislation; liability for wrong doing of minors; propaganda of healthy lifestyle. The special focus is on educational policy oriented to the formation of civicism, tolerance and patriotism, positive social environment in the polycultural region (Solomin, 2012).

To realize the issues of volunteering and educational policy of the university the Center of social research of students has been working in the Mari State University since 2013. During the initial phase the Center had several purposes such as research of social and economic problems of education at university, study of the occupational guidance and their adoption, revelation of problems of physical training and formation of students 'healthy lifestyle, participating of students-volunteers in municipal and regional elections, participating in volunteering as factor of formation of their civil position.

Students-volunteers of the Mari State University created and implemented a range of questionnaires and social forms which aim is to reveal their own skills through self-enquiry, research different social, economic and legal aspects of their life, uplevel heir knowledge and attract more students to the system of self-enquiry (Weston, 2013) 
Students-volunteers also take part in information processing through making diagrams, functional connections, revelation certain qualities and properties so students of the university act as active researchers. Moreover, the Center of social research of students acts as an important tool in the education system of the modern university because it allows to make external and internal monitoring of the students environment, correct forms and methods of work with students.

One of such social researches is a survey which aim is to clarify the ideas of the youth about volunteering and its role to form enabling social and cultural space in the Mari State University. The results of the survey are of the research interest.

\section{Results and Discussions}

The survey of the students revealed that the motives of participation in volunteering firstly have only close personal character and range as follows: "receiving practical experience" (48\%), "it is more interesting to live" (27\%), "making new friends" (20\%). Only $5 \%$ of students said that their main motive of volunteering is a motive "to do good to other people". In our opinion, such structure of the motivation is because of the lack of information about organization of volunteering. This is evident from the fact that the priorities in motivation of volunteers who have great experience in this field are of another nature: $77,8 \%$ of 27 interviewed students noticed "doing good to other people", 14,7\% - "receiving practical experience", $7,4 \%$ - "making new friends" (Chart 1 ).

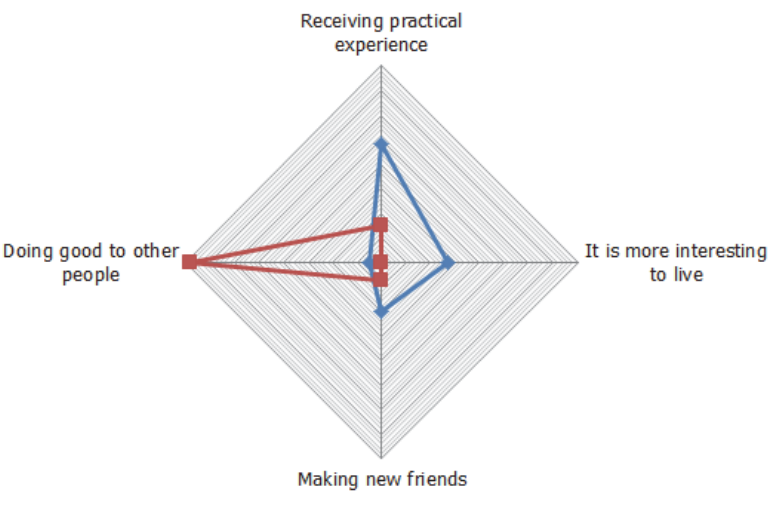

\section{Chart 1.}

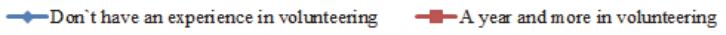

The main priority directions for students active concerning with volunteering.

\section{Chart 2.}
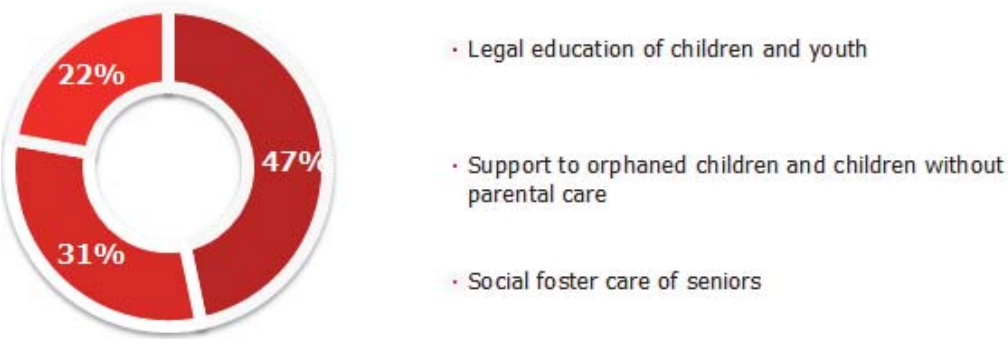

- Social foster care of seniors

According to the students-volunteers` opinion the main personal characteristics for volunteering should be "confidence" (77,8\%), "leadership skills" (54\%), "sociability" (35\%), "sympathy and intelligence" (20\%). As a result of volunteering students "became more confident" (62\%), "make contact easier with each other" $(22,2 \%)$. Only $5 \%$ noticed that nothing changed in their personality.

Answers to the question "Who is a volunteer according to your opinion?" are present at the Chart 3. 


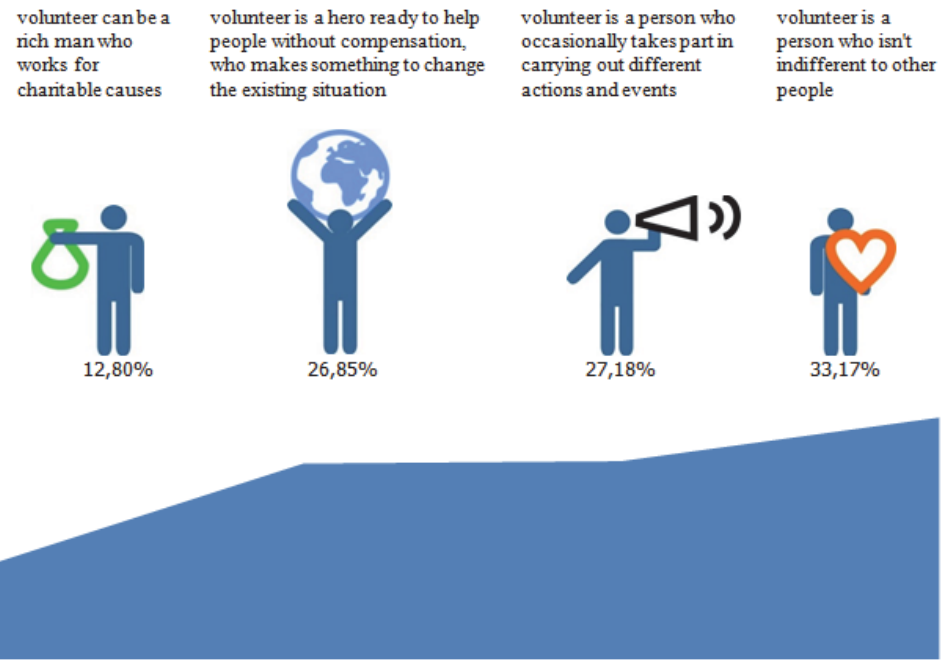

Chart 3.

In answer to the question "Do you take part in volunteering?" $58,45 \%$ of students say that they have already take part in volunteering in different areas; $25,73 \%$ of students do not take part in volunteering; $15,82 \%$ of students intend to take part in it.

In answer to the question about time which students are ready to spend per week on socially useful activity or volunteering on a voluntary basis the following results were received (Chart 4).

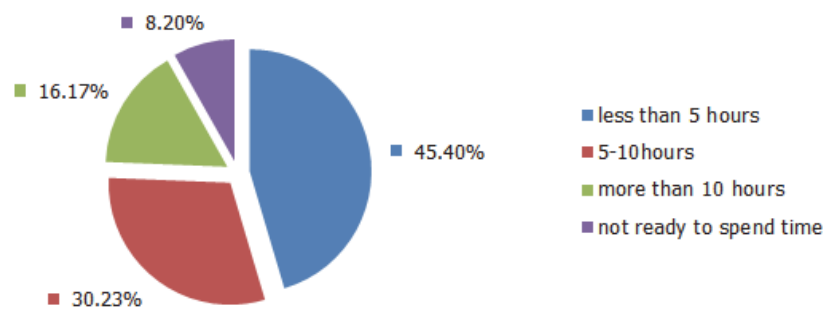

Chart 4.

In answer to the question "What do you think about volunteering among the youth?" the following results were received (Chart 5): no one of the students noticed the variant that volunteering is the waste of time; $54,65 \%$ of students noticed the positive attitude; $25,73 \%$ of students said that they did not belong to volunteers; $19,62 \%$ of students shown their negative attitude to volunteering (it take a lot of time which I can spend on other more useful activities).

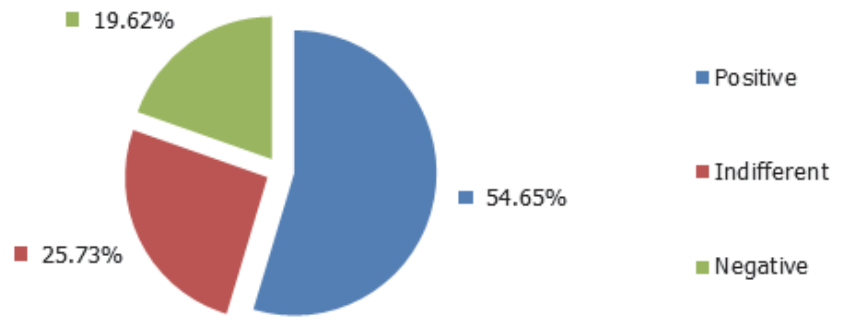

\section{Chart 5.}

The following set of answers were received to the question about the need of volunteers to the society: "yes" - 75,20\%; "no" - 25,80\%.

The research suggested that the organization of volunteering at the university will offer to solve systematically not only the problem of students' interfering in socially important activity (Pankova, 2006) but also to rise the social activity of students, form their civil position, bring up patriotism and the skill to live and study in polycultural, multilinqual and 
multiconfessional environment (Matis, 2012).

The evaluation of the activity of volunteers is regularly made by social partners who fill in the blank of response. To such partners belong the educational organizations of the city and the Republic Mari El. External experts notice that volunteers present the material in lay terms and have enough knowledge, they can answer all questions of students after presenting the lecture material, use interactive technologies (video-cases, multimedia presentations, business video games) and other active forms and methods of group work with teenagers.

The main purpose of the modern stage of the development of social and cultural space of the university is the achievement of high culture of organization of educational work at the university, creation of humanist (person oriented) education system pervading all the spheres of work in the Mari State University. The principle of tolerance becomes one of the leading principles of educational work and supposes the existence of freedom of speech, approaches, and different ideas to solve the same problems, tolerance to opinion of other people, consideration of others, tolerance to other way of life and behavior of people not contradicting to the law, use of educational potential of ethno-cultural environment of the university.

According to this purpose the social research of foreign students was made at the university which gave interesting results.

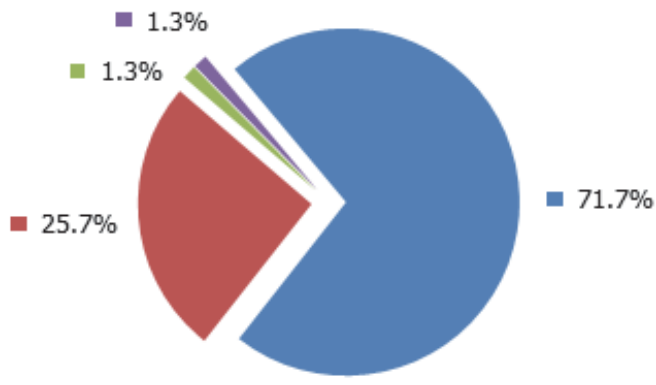

$$
\begin{aligned}
& \text { - Yes } \\
& \text { nather yes } \\
& \text { Rather no } \\
& \text { no }
\end{aligned}
$$

Chart 6.

The answers to the question "Do you agree with the statement that the society becomes richer and more cultural when people of different nationalities live next door?"

The majority of foreign students agree with the statement that the society becomes richer and more cultural, when people of different nationalities live next door (98\%).

According to the results of the survey more than a half of foreign students have positive attitude to other nationalities (73\%). But over a quarter of students notice their negative attitude to other nationalities (27\%) (Chart 7).

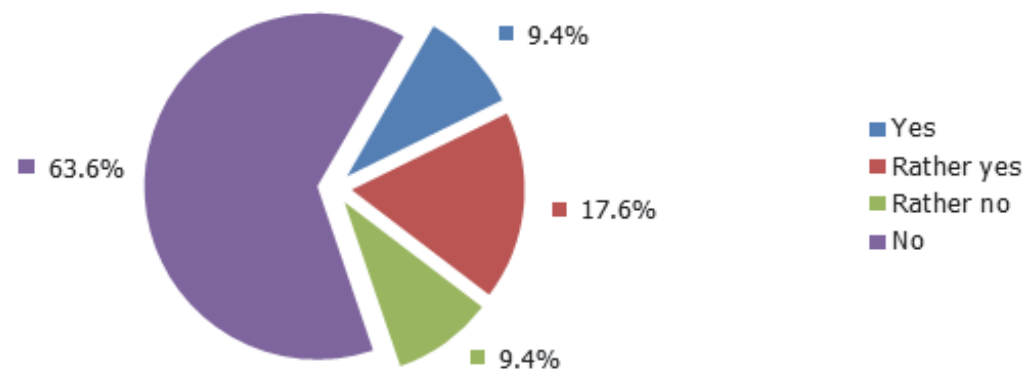

Chart 7.

The research has found that volunteering gives a great opportunity to socialize foreign students. Interfering foreign students in social and cultural space of the university not as a foreign component but as an equal partner promote their effective adoption, social and cultural integration and harmonization of interethnic relations.

For the purpose of generalization of results of volunteering the department of educational work and youth policy of the Mari State University jointly with the Council of students and postgraduates held "a round table" on organization of volunteering of students at the Mari State University in April 2014, in December 2014 the interregional forum following to the results of the work of The Volunteer school took place. 
The analysis of the work of these stages gave the possibility to make a SWOT-analysis of volunteering focused on the searching for positive and negative factors of organization of volunteering, determination of problems and the perspective of its development. The results are given in the Table 1 "Analyses of volunteering at the Mari State University".

Table 1. Results of SWOT-analyses of volunteering at the Mari State University

\begin{tabular}{|c|c|}
\hline Positive factors & Negative factors \\
\hline 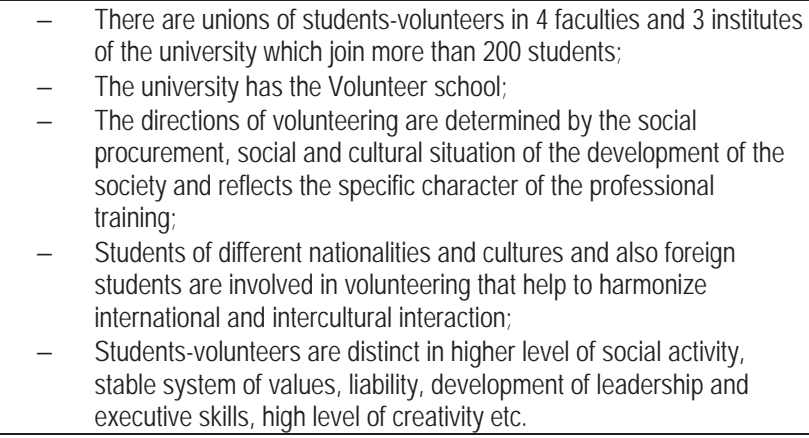 & $\begin{array}{l}\text { - } \quad \text { Lack of centralized coordination in volunteering of the } \\
\text { university; } \\
\text { - The teaching staff underestimates the significance of } \\
\text { volunteering in the education system of the university ; } \\
\text { Insufficient motivation of students to participate regularly in } \\
\text { volunteering; } \\
\text { - Unformed reflexive component of the activity of students- } \\
\text { volunteers, failure to estimate the results of his or her } \\
\text { activity and determine its future prospects. }\end{array}$ \\
\hline Problems of the development & Problems of functioning \\
\hline $\begin{array}{ll}\text { - } & \text { To create volunteer units in all the structural departments of the Mari } \\
& \text { Sate University; } \\
\text { - } & \text { To extend a range of socially important directions of volunteering; } \\
\text { - } & \text { To make trainings for students-volunteers aimed to form the } \\
& \text { motivation to volunteering and capacity for reflection; } \\
\text { - } & \text { To extend social partnership within the system of volunteering; } \\
- & \text { To activate the participation in international voluntary programs; } \\
\text { - } & \text { To involve the teaching staff together with student in volunteering } \\
\end{array}$ & $\begin{array}{l}\text { Non-addition of formal attitude to the organization of } \\
\text { volunteers in the faculties and institutes (chase of large- } \\
\text { scale participation, lack of analysis of the results); } \\
\text { - Wrench of values of students, orientation to financial } \\
\text { benefit; } \\
\text { - Unformed citizenship of certain groups of students and/or } \\
\text { failure and unwillingness to realize in socially important } \\
\text { activity. }\end{array}$ \\
\hline
\end{tabular}

According to the SWOT-analysis of volunteering it was guide that there is a developed structure of volunteering at the Mari State University, the work on different directions of social activity is made. Volunteering at the Mari State University has a multinational structure which has a positive impact on formation of toleration. Volunteers of the Mari State University constantly develop their skills, put into practice in social institutions - kindergartens, orphan asylums and different social organizations of the city and the republic. Volunteers are distinct in high level of liability to decisions, responsible. But there are some problems of functioning of volunteer units at the university - lack of centralized coordination, the teaching staff underestimates the significance of the activity of students etc. For this reason it is necessary to extend the contacts with social partners, form a unique approach to volunteering in the education system of modern students.

The question "What do students get from the participation in volunteering?" is also important. In our opinion, first of all students-volunteers get a lot of components of professional competency: skill to interact with different age and social groups, culture of pedagogical communication (oratorical skill, declamation). Secondly, active citizenship is formed. Thirdly, enabling social and cultural space is created with the participation of students that is confirmed not only by the outward glance but also by the third party.

However, it becomes apparent that organization of volunteering sets up a special claim to special training and coordination of the activity of volunteers who work in education particularly preparation and presentation of educational trainings with volunteers-activists which aim is to form psychological and motivation components of their activity; formation of skills to interact with different social and age groups; acquirement of knowledge in law, psychology and pedagogy.

\section{Conclusion}

Therefore, volunteering is a voluntary consolidated socially important activity of students based on principals of law, voluntariness, understanding personal and social importance of their activity by volunteers, continuity and consistency of work, publicity and self government.

Experience of volunteering at the Mari State University only in 2013-2015 was presented on All-Russian and international events: International forum "iVolga" (the Samara Region), international youth educational forum "Seliger" 
(the Tver Region), International Finno-Ugrian forum of students (Yoshkar-Ola), All-Russian forum "Russian students" (Kazan) etc.

In conclusion it is worth while mentioning that the problem of the development of volunteering has a critical level. According to this purpose the government institutions, the society as a whole and each citizen should join to render humanitarian assistance, technical support, observe human rights, and raise a level of welfare, democratization of the society, form tolerance and consolidate the world. The experience of the Mari State University allows to present the opportunities of the university to realize deferent voluntary programs. The university accumulating staff, material and methodical resources acts as the center of social and cultural space fixing positive social impact to students which protects him or her from antisocial and antihuman actions, supports his or her psychologically and promotes his or her harmonious development and self-education.

\section{References}

Azarova, E.S., Yzsnitskii, M.S. (2008). Psychological determinations of volunteering. Psychology and pedagogic, 306. 121-124.

Bortnikova, T.G. (2012) Social work and volunteering in public associations of ethnic groups abroad. Social and economic phenomena and processes, 12 (046), 440-442.

Chibisova, N.G. (2010). Social and cultural space of the university - basis of cultural capital formation by students . Alma Mater, 8, 1825.

Conception of long-term social and economic development of the Russian Federation till 2020 accepted by the order of the Government of the Russian Federation as of November 17, 2008, N 1662-p [Online] Available: http://www.consultant.ru/document/ cons_doc_LAW_90601/ (May 08, 2015)

Huang, R., Xixi, L. (2014). Chinese College Students Volunteer in the Contemporary International Environment: Facing the Opportunities and Challenges. International Integration for Regional Public Management (ICPM 2014), 335-339. DOI:10.2991/icpm-14.2014.60

Ilinskii, I.M., Sharonov, A.V. (1993). The youth of Russia: tendencies, prospective. Moscow: Molodaya gvardiya.

Kozlov, P., Obidina, Y. (2014). Volunteering as a factor in the formation of civic engagement of young people of the Republic of Mari El. Spiritual sphere of society, 11, 103-109.

Loginova, N.V. (2012). Volunteering as a social phenomenon: experience of presentation of conceptional dictionary. Political linguistics. $3(41), 149-156$.

Lough, B. J. (2011). International volunteers' perceptions of intercultural competence. International Journal of Intercultural Relations, 35, 452- 464. DOI 10.1016/j.jijitrel.2010.06.002

Matis, V.I. (2012). Actualization of culture of international and interconfessional communication. World of science, culture, education, 5 , $147-151$.

Matuzov, N.I., Malko, A.V., Shundikov, K.V. (2004) Legal policy of modern Russia. Legal policy and legal life, 1, 6-27.

Menshchikova, I.Y. (2008). Social work and volunteering: value and practical aspects of interaction at high school. Science research in education. 1, 42-43.

Nezhina, T.G. (2014). Motivation of students to participate in volunteering. Questions of state and municipal governance, 3, 49-71.

Pankova, L.I. (2006). Main factors of formation of value system of students in social and cultural space of the university. Bulletin of Penza State Pedagogical University n.a. V.G. Belinskii, №6, 104-107.

Pushkareva, T.V., Melnikova, N.V. (2013). Volunteering as free charity. Bulletin of Kostroma State University n.a. N.A. Nekrasov, 1, Vol.19, 188-190.

Report of European Center of Not-for-Profit Law «Volunteering - European practice of regulation». [Online] Available: http://www. lawtrend.org/wp-content/uploads/2014/09/ecnl-volonterskaya-deyatelnost-evropejskie-praktiki-regulirovaniya.pdf (May 08, 2015)

Resolution A/RES/56/38 "Recommendation on support for volunteering" General Assemble of the United Nations. [Online] Available: http://daccess-ods.un.org/TMP/350477.509200573.html (May 08, 2015)

Sherraden, M. S., Lough, B., Moore McBride, A. (2008). Effects of International Volunteering and Service: Individual and Institutional Predictors. Voluntas, 19, 395-421 DOI 10.1007/s11266-008-9072-x.

Sikorskaya, L.E. (2006).Volunteering as factor of formation of humanistic focus of student in modern society. Knowledge. Understanding. Skill,1, 211-213.

Sikorskaya, L.E. (2009). Volunteering as form of labour nurturing of students. Knowledge. Understanding. Skill, №1, 163-168.

Solomin, V.P. Lavrenko, A.V., Smorgunov, V.Y. (2012). State policy for creation of legal basis of volunteering as an effective tool of socialization of the youth and formation of civic values. Universu: Bulletin of Herzen University, 3, 15-24.

Strategy of state youth policy in the Russian Federation. [Online] Available: http://old.mon.gov.ru/press/news/3318,print/ (May 08, 2015)

Weston, C., Guardini, E., Minnion, A., Kwiatkowska, G. (2013) Volunteering and learning in HE: exploring and acknowledging student experience. Research in teacher education, Vol.3, 2, 7-14.

Ying, L., Linquan, P. (2015). Voluntary Service: The Important Carrier of Ideological and Political Education of College Students. Canadian Social Science, Vol. 11, 2, 98-105 DOI: 10.3968/6348.

Zheleznovskaya, I.A., Tarasova, T.L. (2011). Civic and national education of students at colleges through the system of volunteering. Science research in education, 12, 16-18. 
